\title{
Pergaulan Laki-Laki Dan Perempuan Semasa Pertunangan Pada Keluarga Elit Agama Dan Masyarakat Blater Di Desa Kapedi Kecamatan Bluto Kabupaten Sumenep
}

\author{
Dhani Ramdhani \\ (Fakultas Syariah IAIN Madura, Jl. Raya Panglegur Km. 4, Pamekasan, \\ email: danie.kelling@gmail.com)
}

\begin{abstract}
Abstrak:
Perkawinan merupakan perbuatan ibadah dalam kategori ibadah umum, dengan demikian dalam melaksanakan perkawinan harus diketahui dan dilaksanakan aturan-aturan perkawinan dalam hukum Islam. Sebelum memasuki pintu perkawinan, yang harus pertama kali di perhatikan ialah hendaknya kedua belah pihak dapat saling mengenal pribadi masing-masing, baik segi karakter, sisi agama, kehormatan atau kemuliaan, silsilah keturunan atau nasab, maupun kecantikan dan ketampanannya. Pertunangan bukan termasuk syarat atau rukun dalam perkawinan. Namun demikian, praktek yang berlaku di masyarakat menunjukkan bahwa pertunangan merupakan langkah pendahuluan yang hampir pasti dilakukan dalam masyarakat.
\end{abstract}

\section{Kata Kunci:}

Pergaulan, Pertunangan, Masyarakat

\section{Pendahuluan}

Perkawinan merupakan perbuatan ibadah dalam kategori ibadah umum, dengan demikian dalam melaksanakan perkawinan harus diketahui dan dilaksanakan aturan-aturan perkawinan dalam hukum Islam. ${ }^{1}$ Sebelum memasuki pintu perkawinan, yang harus pertama kali diperhatikan ialah hendaknya kedua belah pihak dapat saling mengenal pribadi masing-masing, baik segi karakter, sisi agama, kehormatan atau kemuliaan, silsilah keturunan atau nasab,

1 Abd. Shomad, Hukum Islam: Penormaan Prinsip Syari'ah dalam Hukum Indonesia, (Jakarta: Kencana, 2010),. 275. 
maupun kecantikan dan ketampanannya. Dalam hal ini, Islam menganjurkan agar dipilih calon istri (suami) karena agamanya, bukan hanya karena kecantikan, kekayaan, dan kedudukannya semata-mata. Dengan agama dan akhlak yang baik, seseorang akan lebih mudah mencapai maqashid Syariah dari sebuah pernikahan, sehingga dapat menjaga hak dan kewajibannya. ${ }^{2}$

Dalam hukum Islam, tidak dijelaskan tentang cara-cara bertunangan. Hal itu memberikan peluang bagi kita untuk melaksanakan dengan adat istiadat yang berlaku selama tidak bertentangan dengan ajaran Islam. Dimana pergaulan selama masa tunangan baik bagi keluarga elit agama maupun masyarakat biasa, yang tidak jauh beda antara adat bagian elit agama dan masyarakat biasa. Upacara pinangan atau tunangan dilakukan dengan berbagai variasi, dan cara yang paling sederhana, pihak orang tua calon mempelai laki-laki mendatangi pihak calon mempelai perempuan, untuk melamar dan meminang. ${ }^{3}$

Setelah terjadi peminangan, dan pasangan itu diterima oleh pihak yang dipinang, berarti secara tidak langsung kedua belah pihak dengan persetujuan disertai kerelaan hati telah mengadakan perjanjian yang langsung atau tidak langsung. Hal itu berarti calon mempelai telah terikat dengan pertunangan.

\section{Pengertian dan Hukum Pertunangan}

Pertunangan disebut juga dengan peminangan. Peminangan merupakan pendahuluan perkawinan yang disyari'atkan sebelum ada ikatan perkawinan didasarkan kepada penelitian dan pengetahuan serta kesadaran masing-masing pihak.

Peminangan adalah proses melamar laki-laki kepada seorang perempuan untuk menyatakan niat ingin menikahi perempuan yang diinginkan. Sedangkan pertunangan adalah proses menunggu untuk dilangsungkan akad nikah antara pihak laki-laki dan perempuan yang diberi ikatan seperti cincin dan pemberian lainnya.

Hukum melihat pinangan, melihat wanita pinangan yang dipinang adalah sesuatu yang di anjurkan oleh syari'at. ${ }^{4}$ Meskipun

2 Mahmud Syaltut, Akidah dan Syariah Islam, alih bahasa Fachruddin Hs, (Jakarata: Bumi Aksara, 1998), 158.

3 Beni Ahmad Saebani, Figh Munakahat 1, (Bandung: Pustaka Setia, 2001),. 146-147.

4 Sulaiman Ahmad Yahya Al-Faifi, Fikih Sunnah Sayyid Sabiq (Jakarta: Pustaka AlKautsar, 2013),. 409-410. 
pria dengan wanita telah bertunangan, pada hakikatnya mereka belum halal untuk bergaul terlalu dekat, bahkan bersalaman saja diharamkan oleh Allah SWT, apalagi berpelukan dan berdua-duaan tanpa ada yang mengawasinya. Pada dasarnya, pertunangan hanyalah upaya untuk mengenal lebih dekat antara dua pihak, sehingga ketika menikah, mereka tidak merasa tertipu, dan rumah tangganya menjadi tentram, damai, dan abadi. ${ }^{5}$

\section{Syarat-syarat Pertunangan}

Dalam prosesi pertunangan ada syarat-syarat yang harus di penuhi terlebih dahulu sebelum melakukan pertunangan. Syaratsyarat pertunangan tersebut nantinya akan menentukan boleh atau tidaknya melakukan pertunangan. Apabila syarat pertunangan bisa dipenuhi maka pertunangan bisa dilangsungkan. Namun, ada beberapa syarat yang tidak mengikat dan tidak mengakibatkan batalnya pertunangan, hanya saja jika syarat ini dipenuhi dalam melakukan pertunangan akan lebih baik.

Dengan penjelasan di atas, perempuan yang boleh dipinang adalah sebagai berikut:

1. Tidak sedang dalam pinangan orang lain;

2. Tidak sedang dalam masa iddah raj'iyyah;

3. Tidak ada larangan syar'i untuk dinikahi;

4. Perempuan yang sedang masa iddah karena ditalak $b a^{\prime}$ in, sebaiknya dipinang secara rahasia. ${ }^{6}$

Sedang menurut Fiqh Islam talah menggariskan beberapa syarat dalam pertunangan itu menjadi dua, yaitu:

1. Syarat laziminyah adalah syarat yang wajib dipenuhi sebelum pertunangan itu dilakuakan. Syarat laziminyah ini sangat menentukan sah dan tidaknya sebuah pertunangan jika syarat laziminyah terpenuhi maka pertunangan menjadi sah, tetapi bila tidak terpenuhi maka pertunangan itu menjadi batal demi hukum. Yang termasuk syarat laziminyah adalah:

a. Wanita yang akan dipinang bukanlah wanita-wanita yang termasuk atau telah mejadi mahrom dari laki-laki yang akan meminangnya.

\footnotetext{
5 Saebani, Figh Munakahat 1,. 151.

6 Saebani, Figh Munakahat 1,. 149.
} 
b. Wanita yang akan dipinang bukanlah wanita yang sudah atau dalam pinangan laki-laki lain, kecuali laki-laki sebelumnya telah melepaskan haknya atau mengijinkannya untuk dipinang.

c. Wanita yang akan dipinang bukan wanita yang sedang dalam menjalani massa iddah.

2. Syarat mustahsinah adalah dengan memenuhi syarat-syarat itu orang dapat ihsan (kebaikan) dari perbuatan yang disyaratkan.

Syarat mustahsinah bukanlah syarat yang wajib dipenuhi sebelum pertunangan dilakukan, sebagaimana halnya dengan syarat laziminyah, tetapi ini hanya merupakan sesuatu yang sangat dianjurkan kepada seorang laki-laki yang akan meminang seorang wanita, agar rumah tangga yang akan dibina kelak akan terjamin kelangsungan hidupnya dengan sebaik-baiknya.

Yang termasuk syarat mustahsinah adalah:

a. Sejodoh (khafa'ah)

b. Wanita yang memiliki sifat kasih sayang dan subur (beranak) maksudnya wanita yang dipinang yang peranak, harus budi pekerti, penuh kasih sayang serta diduga memiliki banyak anak.

c. Hendaknya mengetahui keadaan jasmani dan budi pekerti dari wanita yang dipinang begitu pula sebaliknya, si

d. Terpinangpun hendaknya mengetahui keadaan si peminang.

Syarat mustahsinah ini sifatnya anjuran kepada seorang lelaki yang akan meminang seorang wanita, agar meneliti terlebih dahulu wanita yang akan dipinang itu. Dalam melakukan kegiatan penelitian itu seorang laki-laki perlu memperlihatkan hal-hal sebagai berikut:

a. Wanita yang dipinang itu hendaknya sepadan (sekutu) dengan laki-laki yang meminangnya.

b. Wanita yang dipinang itu hendaknya wanita yang mempunyai sifat kasih sayang dan wanita yang peranak.

c. Wanita yang dipinang itu hendaknya wanita yang jauh hubungan darahnya dengan laki-laki yang meminangnya.

d. Hendaknya mengetahui keadaan-keadaan jasmani, budi pekerti dan tabiat wanita yang akan dipinang.

Dalam pasal $12 \mathrm{KHI}$ menyebutkan bahwa: 
a. Pertunangan dapat dilakukan terhadap seorang wanita yang perawan atau terhadap janda yang telah habis masa iddahnya.

b. Wanita yang ditalak suami yang masih iddah raj'i haram dan dilarang untuk dipinang.

c. Dilarang juga meminang seorang wanita yang sedang dipinang pria lain selama pinangan pria tersebut belum putus atau ada penolakan dari pihak wanita.

d. Putunya pinangan dari pihak pria, karena adanya pernyataan tentang putusnya hubungan pinangan atau secara diam-diam si pria yang meminang telah menjahui dan meninggalkan wanita yang dipinang.

\section{Hikmah dan Tujuan Pertunangan}

Pertunangan merupakan terbentuknya hal yang utuh yang awalnya terpisah laki-laki dan perempuan. Pertunangan juga untuk lebih menguatkan ikatan yang dilakukan sesudah pertunangan, yaitu perkawinan, karena kedua belah pihak sudah mengenal. Seperti halnya bangunan agar terciptanya suatu ciptaan yang utuh dan yang kokoh, dibutuhkan suatu fondasi, yaitu mulai dari perhitungan yang akurat, pelajaran, serta perencanaan yang matang. Begitu pula dengan suatu ikatan perkawinan, tidak hanya sebagai bahan pelampiasan nafsu yang akhirnya "habis masis sepah dibuang," tapi lebih dari itu, perkawinan selain sebagai sunnatullah juga untuk membangun keluarga dan menjalin silturrahim.

Pada dasarnya tujuan dari pertunangan dengan perkawinan tidaklah jauh berbeda. Secara eksplisit, tujuan dari pertunangan memang tidak disebutkan seperti halnya dalam perkawinan, namun secara implisit, tujuan dari pada pertunangan dapat dilihat dari syarat-syarat yang ada dalam pertunangan.

Pertunangan itu sendiri mempunyai tujuan, tidak lain yaitu untuk menghindar dari kesalah pahaman antar kedua belah pihak, dan juga, agar perkawinan itu sendiri berjalan atas pemikiran yang mendalam dan mendapat hidayah. Lebih jauh lagi, suasana kekeluargaan nantinya akan berjalan erat anatara suami istri, dan anggota keluarga lainnya.

Yang terpenting dari tujuan pertunangan bila ditinjau secara umum adalah: 
1. Lebih mempermudah dan memperlancar jalannya masa perkenalan antara pihak pertunangan dan yang dipinang beserta dengan keluarga masing-masing. Hal ini dikarenakan tak jarang bagi pihak pertunangan atau yang dipinang sering ada salah satu yang kurang dewasa dalam menjalani proses pengenalan kepada calon pendampingnya.

2. Supaya di antara keduanya rasa cinta dan kasih sayangnya lebih cepat tumbuh.

3. Menimbulkan efek ketentraman jiwa dan kemantapan hati bagi pihak yang akan menikahi atau yang akan dinikahi, tanpa adanya pihak-pihak yang mendahului.

\section{Batas-batas Pergaulan Dalam Masa Pertunangan}

Batas-batas dalam pertunangan tersendiri agar tidak terjadi pergaulan yang bebas dimana sudah diluar kode etik dalam agama. Tidak dapat di pungkiri bahwa setiap muslim berlaku dengan etikaetika pada setiap perbuatannya, yang disebut qubh (keindahan atau kesopanan). Akan tetapi, nilai etika itu selamanya dapat dinalar dengan otak manusia sehingga pada suatu saat manusia sepenuhnya terikat dengan wahyu Tuhan yang kemudian mengantarkan pada sesuatu yang tidak sopan.

Untuk kepentingan perkawinan itu sendiri, Islam sudah mengaturnya, yang apabila dilakukan dan dipelihara, niscaya akan menjadikan sebagai sumber kekuatan dan menjauhkan dari renikrenik kehidupan yang dapat menghancurkan kekokohan keluarga. Selain itu, ada juga yang menjadi perhatian utama sebelum memasuki perkawinan, yaitu mengesampingkan sikap egois dari masing-masing dan tidak hanya memandang perkawinan hanya sebelah mata, yang hanya menurut pada kebutuhan. Dengan begitu, keduanya dapat saling mengenal dan menerima dengan ikhlas kekurangan masingmasing. ${ }^{7}$

\section{Metode Penelitian}

Penelitian ini menggunakan pendekatan kualitatif. Penelitian ini jenis data dalam riset kualitatif adalah transkip hasil wawancara,

7 Abd Qorib Hidayatullah, Pandangan Ulama' Terhadap Pergaulan Laki-laki dan Perempuan Selama Masa Bhekalan, Skripsi UIN Maulan Malik Ibrahim Malang (Malang: 13 November 2009),. 45. 
hasil observasi, yang oleh subjek penelitian sesuai dengan seperangkat pertanyaan yang dikemukakan peneliti dengan merujuk pada focus penelitian yang ada sebagai pedoman. sumber data utama dalam penelitian kualitatif ialah kata-kata dan tindakan selebihnya adalah data tambahan seperti dokumen dan lain-lain. Berkaitan dengan hal itu, pada bagian ini jenis data dibagi ke dalam kata-kata, tindakan, sumber data tertulis, foto dan statistik.

\section{Hasil dan Pembahasan}

Pertunangan merupakan langkah awal bagi calon suami/istri untuk melakukan pernikahan. Dalam masa pertunangan ketentuan atau larangan dalam pergaulan kedua pasangan tersebut sama halnya dengan pergaulan laki-laki dan perempuan yang bukan muhrim. Pemahaman masyarakat di Desa Kapedi tentang pergaulan laki-laki dan perempuan semasa pertunangan berbeda-beda. Sebagian masyarakat ada yang mengatakan pergaulan terlalu bebas saat bertunangan dan ada juga yang mengatakan pergaulannya dijaga oleh orang tuannya saat bertunangan.

Semasa pertunangan merupakan masa yang sangat kritis, masa untuk melepaskan ketergantungan terhadap orang tua dan berusaha mencapai kemandirian sehingga dapat diterima dan diakui sebagai orang dewasa. keberhasilan para remaja melalui masa transisi sangat dipengaruhi oleh faktor biologis (faktor fisik), kognitif (kecerdasan intelektual), psikologis (faktor mental), maupun faktor lingkungan. Dalam kesehariannya, remaja tidak lepas dari pergaulan dengan remaja lain. remaja dituntut memiliki keterampilan sosial (social skill) untuk dapat menyesuaikan diri dengan kehidupan seharihari. keterampilan-keterampilan tersebut meliputi kemampuan berkomunikasi, menjalin hubungan dengan orang lain, mendengarkan pendapat/ keluhan dari orang lain, memberi / menerima umpan balik, memberi/ menerima kritik, bertindak sesuai norma dan aturan yang berlaku dan lain-lain.

Oleh sebab itu ada beberapa prinsip etika dalam pergaulan laki-laki dan perempuan semasa pertunangan atau masa remaja, hal tersebut menurut Rachmad Djadmika ${ }^{8}$ adalah sebagaimana berikut:

a. Hak dan kewajiban

\footnotetext{
8 Rachmad Djadmika, System Etika Islam (Akhlak Mulia), (Surabaya: Pustaka Islam, 2007),. 84 .
} 
Hak kita memang layak untuk kita tuntut, tapi juga jangan sampai meninggalkan kewajiban kita sebagai makhluk sosial.

b. Tertib dan disiplin

Selalu tertib dan disiplin dalam melakukan setiap aktivitas. Disiplin waktu biar nggak keteteran

c. Kesopanan

Senantiasa menjaga sopan santun, baik dengan teman sebaya atau orang tua dan juga guru dimanapaun dan kapanpun.

d. Kesederhanaan

Bersikaplah sederhana.

e. Kejujuran

Jujur akan membawa kita ke dalam kebenaran. Bersikap jujurlah walau itu pahit.

f. Keadilan

Senantiasa bersikap adil dalam bergaul. Tidak membeda-bedakan teman.

g. Cinta Kasih

Saling mencintai dan menyayangi teman kita agar terhindar dari permusuhan.

h. Suasana \& tempat pergaulan kita

Ini sangat penting juga buat remaja dalam menjalani kehidupan.

Masyarakat keluarga elit agama dan masyarakat blater di Desa

Kapedi berpendapat akan peran tua mengontrol pergaulan anaknya selama bertunangan. Di sini peran orang tua sewaktu mengontrol anaknya pada keluarga elit agama peran orang tua itu benar-benar aktif untuk menjaga pergaulan anaknya selama bertunangan dan di masyarakat biasa peran orang tua mengontrol anaknya tidak terlalu aktif, karena orang tua memberi kebebasan kepada anaknya selama bertunangan.

Sangat wajar dan logis jika tanggung jawab mengontrol pergaulan anaknya selama pertunangan terletak di tangan kedua orang tua dan tidak bisa dipikulkan kepada orang lain, karena dia adalah darah dagingnya. Tanggung jawab yang perlu disadarkan dan dibina oleh kedua orang tua terhadap anak antara lain adalah :

a. Adanya motivasi atau dorongan cinta kasih yang menjiwai hubungan orang tua dan anak

b. Pemberian motivasi kewajiban moral dan sebagai konsekuensi kedudukan orang tua terhadap keturunanya 
c. Tanggung jawab sosial adalah dari keluarga yang pada giliranya menjadi tanggung jawab masyarakat, bangsa dan Negara.

d. Memelihara dan membesarkan anaknya

e. Memberi pendidikan dengan berbagai ilmu pengetahuan dan ketrampilan yang berguna bagi kehidupan ank kelak sehingga bila ia telah dewasa akan mampu mandiri. ${ }^{9}$

Pandangan masyarakat tentang pergaulan laki-laki dan perempuan semasa pertunangan di tinjau dari hukum Islam banyak yang mengatakan laki-laki dan perempuan masih tidak boleh bertemu, duduk berdua serta berjalan-jalan karena hukumnya masih haram.

Tapi sebagian masyarakat Desa Kapedi telah menyadari hukum pergaulan laki-laki dan perempuan semasa pertunangan, namun batas kewajaran dalam pergaulan yang sering menjadi alasan memberikan kebebasan. Padahal dalam hukum Islam sudah dijelaskan kewajaran hanyalah sebatas melihat calon tunangan saat lamaran bukan kewajaran dalam kebersamaan atau pergaulan.

Dan di Desa Kapedi masih cenderung mengikuti alurnya zaman sehingga kebanyakan yang tidak mengikuti apa yang dilarang oleh Syari'at Islam.

Pertunangan hanyalah merupakan janji akan menikah. Oleh sebab itu pertunangan dapat saja diputuskan oleh ssalh satu pihak, karena akad dari pertunangan ini belum mengikat dan belum pula menimbulkan adanya kewajiban yang harus dipenuhi oleh salah satu pihak.

Sebagian masyarakat beranggapan bahwa apabila mereka sudah bertunangan, mereka merasa sudah ada jaminan menjadi suami istri, tidak jelas apa yang melatarbelakangi anggapan masyarakat tersebut menjadi sesuatu yang dijadikan tradisi. Oleh karena itu hal ini patut mendapat perhatian semua pihak. Karena tidak mustahil dengan adanya kelonggaran norma-norma etika sebagian masyrakat, terlebih yang bertunangan akan menimbulkan penyesalan di kemudian hari, apabila mereka terjebak ke dalam perzinaan.

Dalam hukum Islam, tidak dijelaskan tentang cara-cara pertunangan. Hal itu memberikan peluang bagi kita untuk

\footnotetext{
9 Nurul Zuriyah, Pendidikan Budi Pekerti dalam Perspektif Perubahan, (Jakarta: Bumi Aksara, 2007),. 74.
} 
melaksanakan dengan adat istiadat yang berlaku dan sesuai dengan ajaran Islam. Dimana pergaulan selama masa tunangan baik bagi keluarga elit agama maupun masyarakat biasa, yang tidak jauh beda antara adat bagian elit agama dan masyarakat biasa. Upacara pinangan atau tunangan dilakukan dengan berbagai variasi, dan cara yang paling sederhana, pihak orang tua calon mempelai laki-laki mendatangi pihak calon mempelai perempuan, untuk melamar dan meminang. ${ }^{10}$

Dalam prosesi pertunangan ada syarat-syarat yang harus di penuhi terlebih dahulu sebelum melakukan pertunangan. Syaratsyarat pertunangan tersebut nantinya akan menentukan boleh atau tidaknya melakukan pertunangan. Apabila syarat pertunangan bisa dipenuhi maka pertunangan bisa dilangsungkan. Namun ada beberapa syarat yang tidak mengikat dan tidak mengakibatkan batalnya pertunangan, hanya saja jika syarat ini dipenuhi dalam melakukan pertunangan akan lebih baik.

\section{Penutup}

Berdasarkan temuan dan pembahasan hasil penelitian di atas. sebagaimana dibahas pada bab sebelumnya dapat disimpulkan berikut ini:

1. Fenomena tentang pergaulan laki-laki dan perempuan semasa pertunangan di Desa Kapedi.

a. Masyarakat Blater saat ini dirasa longgar, dimana oleh kaum laki-laki dijadikan kesempatan untuk dapat berdua dengan tunangannya dan menjadi suatu kebanggaan jika mereka dapat memperlihatkan statusnya yang bertunangan terhadap teman-temannya.

b. Elit Agama yaitu pergaulan pada masa pertunangan benarbenar terjaga yaitu apabila setelah melakukan prosesi tunangan dinikah sirrikan terlebih dahulu. Fenomina lain juga terjadi pergaulan laki-laki dan perempuan di masa tunangan, banyak aturan-aturan agama yang dilanggar. Misalnya, berboncengan, berjabat tangan, bermalam di salah satu rumah pasangan.

\footnotetext{
10 Saebani, Fiqh Munakahat,. 146-147.
} 
2. Peran orang tua mengontrol pergaulan anaknya selama pertunangan baik pada keluarga elit agama dan masyarakat blater di Desa Kapedi.

Masyarakat keluarga elit agama dan masyarakat blater di Desa Kapedi berpendapat akan peran tua mengontrol pergaulan anaknya selama bertunangan. Di sini peran orang tua sewaktu mengontrol anaknya pada keluarga elit agama peran orang tua itu benar-benar aktif untuk menjaga pergaulan anaknya selama bertunangan dan di masyarakat blater peran orang tua mengontrol anaknya tidak terlalu aktif, karena orang tua memberi kebebasan kepada anaknya selama bertunangan.

3. Pandangan masyarakat tentang pergaulan laki-laki dan perempuan semasa pertunangan di tinjau dari hukum Islam bahwa Pandangan masyarakat tentang pergaulan laki-laki dan perempuan semasa pertunangan di tinjau dari hukum Islam banyak yang mengatakan laki-laki dan perempuan masih tidak boleh bertemu, duduk berdua serta berjalan-jalan karena hukumnya masih haram. Tapi sebagian masyarakat Desa Kapedi telah menyadari hukum pergaulan laki-laki dan perempuan semasa pertunangan, namun batas kewajaran dalam pergaulan yang sering menjadi alasan memberikan kebebasan. Padahal dalam hukum Islam sudah dijelaskan kewajaran hanyalah sebatas melihat calon tunangan saat lamaran bukan kewajaran dalam kebersamaan atau pergaulan dan di Desa Kapedi masih cenderung mengikuti alurnya zaman sehingga kebanyakan yang tidak mengikuti apa yang dilarang oleh Syari'at Islam.

\section{Daftar Pustaka}

Shomad, Abd. Hukum Islam: Penormaan Prinsip Syari'ah dalam Hukum Indonesia. Jakarta: Kencana, 2010.

Syaltut, Mahmud. Akidah dan Syariah Islam, alih bahasa Fachruddin Hs. Jakarata: Bumi Aksara, 1998.

Saebani, Beni Ahmad. Figh Munakahat. Bandung: Pustaka Setia, 2001. Faifi, Sulaiman Ahmad Yahya Al-. Fikih Sunnah Sayyid Sabiq. Jakarta: Pustaka Al-Kautsar, 2013. 
Hidayatullah, Abd Qorib. Pandangan Ulama' Terhadap Pergaulan Lakilaki dan Perempuan Selama Masa Bhekalan, Skripsi UIN Maulan Malik Ibrahim Malang. Malang: 13 November 2009.

Djadmika, Rachmad. System Etika Islam (Akhlak Mulia). Surabaya: Pustaka Islam, 2007.

Zuriyah, Nurul, Pendidikan Budi Pekerti dalam Perspektif Perubahan. Jakarta: Bumi Aksara, 2007. 